\title{
Understanding Embodiment Through Lived Religion: A Look at Vernacular Physiologies in an Old Norse Milieu
}

Frog

University of Helsinki

$\begin{array}{ll}\begin{array}{ll}\text { Ero volor allar } \\ \text { vitcar allir } \\ \text { enn seiðberendr }\end{array} & \text { frá Viðólfi, } \\ \text { iotnar allir } & \text { frá Vilmeiði, } \\ & \text { frá Ymi komnthofða, } \\ \text { All volvas are } & \text { from Viðólfr, } \\ \text { all sorcerers } & \text { from Vilmeiðr, } \\ \text { yet seiðr-workers } & \text { from Svarthǫfði, } \\ \text { all giants } & \text { from Ýmir come. }\end{array}$

The materiality of lived religion manifests itself in countless ways. These include fundamental understandings of embodied experience. Understandings of bodies are socially constructed and result in what is called a body image - i.e. a symbolic and iconic model of what our body is (and is not). ${ }^{2}$ The resulting body image can be thought of as an imaginal understanding of the body's physiology. In Western cultures today, medical science is fundamental to people's understandings of the body and how it works. The internalization of the body image occurs in the dynamic dialectic between our empirical experiences and imaginal perceptions on the one hand and, on the other, a full spectrum of circulating discourses $^{3}$ about health, fitness, illnesses, pains, nutrition, muscles, organs, joints, emotions, souls, death, ghosts, psychics, and so on and so forth. As we negotiate these discourses, encounters with

How to cite this book chapter:

Frog. 2019. Understanding Embodiment Through Lived Religion: A Look at Vernacular Physiologies in an Old Norse Milieu. In: Wikström af Edholm, K., Jackson Rova, P., Nordberg, A., Sundqvist, O. \& Zachrisson, T. (eds.) Myth, Materiality, and Lived Religion: In Merovingian and Viking Scandinavia. Pp. 269-30I. Stockholm: Stockholm University Press. DOI: https://doi. org/I0.I6993/bay.j. License: CC-BY. 
medical specialists, with their dazzling technologies, scientific descriptions, diagnoses, remedies and models of health, provide authoritative frames of reference for developing our understanding. The outcome might vary from person to person, but at a social level it results in a biologically defined hegemonic body image, or an image that is the predominantly-shared frame of reference of people in society. In pre-modern cultures, body images were also internalized through the dialectic between perceived experiences and authoritative specialists, but the specialists had very different technologies. We tend to think about technologies in terms of mechanical and electronic devices. However, technologies are basically tools, techniques and strategies for accomplishing tasks. It is thus reasonable to talk about ritual technologies and associated specialists in those technologies. The development of understandings of the materiality of the body and vernacular physiologies can be considered in relation to those technologies and the specialists who use them. On the other hand, there seem to have been multiple technologies associated with different specialists in the Old Norse world. It is not clear that all of these specialists shared a single body image. Consequently, it is reasonable to consider that lived religion may have resulted in different body images for people aligned with different practices and specialists.

The present chapter considers whether there may have been multiple body images co-existing in an Old Norse milieu. This is explored by interrogating the relationship between ritual specialists, the technologies of their practices, and the body image with which the technologies interface. The institutions taken as examples for comparison are berserkir, volur and what will be described as deep-trance specialists. This chapter does not seek to offer a full account of each institution and its sources, which is not possible in a short article. The aim here is to open the question of whether these practices may have been interfaced with different body images. This possibility is not unlike the technology of classic Chinese acupuncture existing alongside Western medicine although the former is interfaced with an incompatible body image based on the movement of life energy along bodily meridians. ${ }^{4}$ However, the Chinese and Western body images are today engaged as alternatives for our biologically defined hegemonic 
understanding of all 'humans'. In the epigraph above, volur and other types of specialists are each defined in terms of a common origin alongside jotnar 'giants'. When 'human' is not defined biologically on the basis of the empirical materiality of the body, it pulls the rug out from under our basic ontologies of social identities and our fundamental modern distinction between 'real' and 'not real'. In its place, we find an ethnocentric construct of 'people like us' from which 'others' can be fractionally differentiated i.e. by potentially subtle increments of individual features - both physically and at an imaginal level. As a consequence, sameness or difference that we would class as supernatural may be equally or more important than empirically observable bodily features. ${ }^{5}$ Our own ontologies incline us to interpret the origin of all volur from Viðólfr in terms of an origin of characteristic practices that are taught and learned and thereby of the social role of a volva. However, when this origin is presented as comparable to the origin of jotnar from Ýmir, it becomes necessary to question whether volur are being distinguished as somehow physiologically different from the hegemonic norm of 'people like us', and, if so, how such differentiation relates to the ritual technologies on which this social identity relies.

\section{Background}

There has been a great deal of discussion surrounding conceptions of 'souls' and 'spirits' connected with vernacular religion, magic and ritual in an Old Norse milieu. ${ }^{6}$ The conclusions of these studies vary in relation both to the material foregrounded and to the scholar's focus and methodology. Scholars tend to focus on the term and concept of seiðr, which gets connected to the volva, deep-trance specialists, as well as being linked to a variety of other magic and ritual practices. The orientation of these studies is customarily to reconstruct and generalize a more or less hegemonic model of the supernatural for the Old Norse world, a model often compared and contrasted with neighbouring and historically related cultures. Berserkir are sometimes addressed in these discussions ${ }^{7}$ but they are not usually seen as performers of seiðr and have generally been at the centre of a separate debate. ${ }^{8}$ 
The present discussion differs from earlier research on the following key points: $a$ ) the focus is on relationships between embodied experience and ritual technologies; $b$ ) ritual practices are approached in terms of technologies that are not assumed to be the same or even necessarily compatible for all varieties of ritual specialist; $c$ ) ritual technologies are considered to interface with body images and understandings of the unseen world, $d$ ) which are reciprocally accessed and internalized through practices and behaviours and the discourse surrounding them; and $e$ ) individuals are considered to relate to specific practices in different ways and to different degrees according to, for example, social role, age, status, occupation, interest and their relationships and interactions with authoritative individuals.

The ethnocentric image of 'people like us' can be assumed to include a hegemonic body image. In his massive comparative study, Clive Tolley argues with a linguistic and philological emphasis that there is a lack of evidence for a Norse conception that 'people like us' had a free-soul. In other words, Tolley argues that an individual's consciousness or 'soul' was not generally conceived as able to leave the body and travel independently of it; he attributes cases that would appear to represent shamanic soul-journeys to Sámi contacts and narrative strategies of 'othering'. ${ }^{9}$ A body image based on a penetrable body boundary without a free-soul appears to have entered North Finnic cultures with an incantation-based ritual technology during the Iron Age. ${ }^{\text {Io }}$ This body image allowed an individual to affect things at a distance through will, intention and perception, but consciousness could not be active independent of the body. ${ }^{\text {II }}$ As I have sought to show elsewhere, the relevant technology was strategically contrasted with, and gradually displaced, inherited forms of shamanism, ${ }^{\text {I2 }}$ and also shamanism among Sámi populations that eventually were linguistically assimilated. ${ }^{\mathrm{I}}{ }^{3}$ Later Scandinavian and FinnoKarelian legend traditions similarly seem to identify the separable

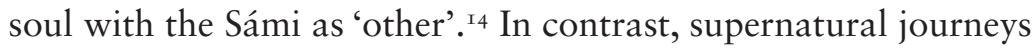
by non-Sámi appear to be conceived of in terms of transformations of the physical body. ${ }^{15}$ Norse emotions and illness seem to have been similarly conceived of in terms of forces and influences (including via perception or awareness as a form of interaction) 
that penetrate the boundary of the body image; that boundary became more open in relation to fear and passivity, or more resilient in relation to strength of will and aggression. ${ }^{16}$ The penetrable body will be tentatively taken as a hegemonic body image of 'people like us' in relation to which a body image with a free-soul was considered 'other'. Importantly, both Scandinavian and FinnoKarelian traditions nevertheless reveal an awareness of multiple body images.

\section{Source Materials and Approach}

Medieval Scandinavian written sources present a rich variety of apparently relevant information ranging from simple vocabulary to elaborate descriptions of magical and ritual practices. The practices are represented from non-specialist perspectives, and they were in all likelihood seen as historically, religiously and culturally 'other' (i.e. belonging to a pre-Christian cultural milieu). Such sources are here inferred to draw on a) contemporary circulating discourse, and potentially also on $b$ ) other written texts that developed in an evolving dialogue with that discourse. The sources thus reflect the individual and social imagination of the past. The authors are Christians - at least in their own eyes. ${ }^{17}$ They were writing for Christian audiences in a form of heritage construction, representing the past as relevant to the present and its social order. ${ }^{18}$ An implicit principle What we say about them, we say about ourselves, can be assumed. The representations of magic and ritual in historically remote contexts can be contrasted with their absence from the so-called contemporary sagas, which should equally be viewed as self-representation. The sources discussed here are Icelandic, where it is doubtful that the volva institution became rooted in the emergence of the insular culture, ${ }^{19}$ where berserkir became emblems of paganism in conversion discourse, ${ }^{20}$ and where, in contrast, what appears to be a deep-trance ritual is described as deciding the legal conversion of Iceland. ${ }^{21}$

Culture is here viewed as "localized in concrete, [socially] accessible signs, the most important of which are actually occurring instances of discourse." ${ }^{22}$ Mythology is approached in the broad sense of systems of symbols and structures that are emotionally 
invested (if potentially contested) models for interpreting experience and understanding seen and unseen worlds with which people interact in the present, past and/or future. From this perspective, the model of a supernaturally empowered agent such as a volva or a berserkr is viewed as a symbol of mythology. Body images are equally viewed as symbolic models for understanding one's own or others' bodies. Such symbols are analysed and interpreted in terms of mythic discourse. Mythic discourse refers to mythology as it is engaged, used, manipulated and communicated by individuals in societies. ${ }^{23}$ It is characterized by the ongoing negotiation of these symbols, their interpretations and significance, which vary like a "kaleidoscope, in perpetual motion" as they are used from different perspectives, in different contexts, and in different combinations. ${ }^{24}$ Although interpretations, valuations and uses may vary, they must remain recognizable in order to function. For example, FIRE DOES NOT BURN BERSERKR (small capitals indicate a symbolic unit) appears to be a motif historically connected with berserkir. ${ }^{25}$ This motif was also taken up in conversion narratives, where it was used in a narrative pattern that asserts the superior power of Christianity: FIRE DOES NOT BURN BERSERKR is affirmed as valid for normal fires, but not for fires consecrated by Christians. ${ }^{26}$ The motif maintains formal continuity as a symbolic, meaning-bearing unit of narration, while the action and the berserkr performing it are interpreted and evaluated from a Christian perspective with a variation that shows the berserkr's inferiority to the power of Christianity.

Methodologically, the present study identifies traditional units of narration related to practices and outcomes of practices that are attached to each type of specialist. Mythic symbols are distinguished according to formal types that are used in structural combinations: an image is a static unit equivalent to the grammatical category of a noun (e.g. VQLLVA, FREE-SOUL, etc.); a motif is a minimal unit that entails the equivalent to the grammatical category of a verb and in which one or more images participate (e.g. voLVA PERFORMS RITUAL); a narrative pattern is a complex conventional sequence of images and motifs that forms a recognizable unit of narration. ${ }^{27}$ Symbolic units are considered to be distinguishable from the language that mediates them, so the word volva may in some cases be used as a general word for 'witch' whereas the 
image volva may be recognizable through description or in relation to a motif or narrative pattern without the term volva. Units of narration are compared and analysed in order to extract information with which they are encoded about practices and practitioners. For example, the motif FIRE DOES NOT BURN BERSERKR indicates that berserkir were thought to remain unburned by fire; the narrative pattern discussed below includes information on a performance situation considered emblematic of a volva. The relevance of this information for historical perspectives is conditional on the units of narration having continuity from the corresponding social institution. The features discussed below do not seem to be adapted from foreign literature and Christian discourse, and they are considered more likely to be rooted in historical phenomena than to be spontaneous inventions without models.

The examples of traditional units of narration discussed below have the characteristics of legends, which conditions them as sources of information. A legend can be described as a short story about a specific encounter that is developed on a traditional plot or motif and engages contestable beliefs about history or the supernatural. Legends are built around concrete elements in an event and/or its outcomes as they would appear to an observer. Scandinavian and Finno-Karelian legends of Sámi shamanism are instructive: their core is simply 'the man lay there as if he were dead and when he woke up he possessed/knew something that was impossible to explain except by magic'; and this core is situated in a framing situation (which may itself be established in the tradition). ${ }^{28}$ The shaman's performance activity tends to remain unmentioned except insofar as it is directly relevant to the plot. Information about performance was (to varying degrees) in circulation, but it was not essential to telling these stories. Instead, it provided a resource for prolongation, for the creation of verisimilitude and for other rhetorical effects (e.g. underscoring "otherness"). In the legends, a shaman's practices are not only reduced to a single, emblematic activity: traditionalization generally excludes the ethnographic information that would be of interest here. Performances by the types of specialists brought into focus below exhibit the same sort of reduction to minimal elements of what an onlooker might observe. 


\section{Berserkir and Berserksgangr}

A berserkr is represented as a supernaturally empowered warrior. Berserkir appear in Old Norse sources as a king's elite guard, the soldiers leading a battle charge, as valorised ancestors of Icelanders, and as exceptionally dangerous vikings. ${ }^{29}$ They often appear as adversaries against whom heroes prove themselves. Presumably by extension, they also appear in conversion narratives as supernatural agents in local communities whose power can be overcome by Christianity. Corresponding ritual and magical performances are not attributed to berserkir, but they are distinguished by berserksgangr 'the going of a berserkr' - wild behaviour characterized by howling and biting on a shield. $3^{\circ}$ The activity state of berserksgangr seems to have manifested a supernatural empowerment linked to the motifs of imperviousness to iron and fire. ${ }^{3 \mathrm{I}}$ The conception of burning has not been investigated in terms of vernacular physiology, although it clearly relates to the ability of fire to affect the body. The motif IRON DOES NOT CUT was linked to a broad range of battle magic, including protective objects ${ }^{32}$ and incantations. ${ }^{33}$ Sources may account for this imperviousness with the motif GAZE BLUNTS IRON, relating it to will and magical agency (not specific to berserkir). However, imperviousness to iron may also simply appear as a "fact" that the protagonist must circumvent, suggesting an inherent quality of the berserkr or berserksgangr. ${ }^{34}$ The body image is emphasized by reference to berserkir as hamrammr. Hamr means 'embodied form' and rammr means '(supernaturally) powerful'. Berserkir are also described as eigi einhamr 'not single-formed', although written sources do not characterize berserkir as shapeshifters per $s e .35$ The motif IRON DOES NOT CUT "leads to many a berserkr being clubbed to death," ${ }^{6}$ which underscores that berserkir are not impervious to injury per se but rather to penetration of the body's boundary.

If the berserkr is accepted as a historical type of supernaturally empowered warrior who performed berserksgangr, it can be inferred that berserksgangr did not occur randomly in society and could be initiated by berserkir when the situation required (e.g. for a duel). It was thus a trained behaviour of heightened (but 
directionally controlled) aggression that could be strategically incited by the berserkr, even if it might also be incited through situational stimuli. Performance practices can then be inferred for both training the behaviour and self-incitement. The emblematic howling and shield-biting can be interpreted as a performance of posturing to build confidence and intimidate adversaries. ${ }^{37}$ These behaviours are also directly comparable to the performance of FinnoKarelian ritual specialists who, through such behaviour, manifest a hyperactive trance that they conceived in terms of "raised" supernatural power which secured the body's boundary. ${ }^{38}$ The heightened aggressive behaviour appears directly linked to supernatural empowerment ${ }^{39}$ that correlates with the motif IRON DOES NOT CUT. Viewed in relation to the hegemonic body image postulated above, this state of raised aggression can thus be viewed as an extension of that physiological model to seal the body's boundary also against weapons, which is directly paralleled in Finno-Karelian battle magic. ${ }^{4 \circ}$ Reference to berserkir as hamrammr and eigi einhamr has been interpreted as a change in the body's form e.g. into that of a bear or wolf. The approach outlined here suggests that these terms centrally referred to a conception of berserksgangr as a supernatural change in hamr that made the body impenetrable without necessarily affecting its outward appearance. ${ }^{4 \mathrm{I}}$ This model is accepted here for the sake of argument.

\section{Volur}

The term volva is commonly associated with supernaturally empowered women who have the power to prophesy, although the term and corresponding image do not invariably co-occur. ${ }^{42}$ Nevertheless, the term volva is particularly associated with a distinct performance situation. Such performances will here be considered as emblematic of the specialist and as central to maintaining the distinct image volva. ${ }^{43}$ The performance situation is encoded as the central scene in the complex narrative pattern that John McKinnell identifies as The hostile young man: a volva is hosted by a patriarch at a feast where she publicly performs prophesies; the young hero disapproves of the event; he does not want to hear his own fortune after others have been told; 
the seeress makes her prophesy anyway and the hero is resentful or aggressively hostile. ${ }^{44}$ The social performance situation is interfaced with the narrative pattern and cannot be significantly altered without changing the narrative pattern itself. This interface would stabilize the social transmission of the performance situation in cultural memory. ${ }^{45}$ When used in the narrative pattern, no additional information about performance is normally included except that the volva's activity was an itinerant practice: she moved from feast to feast in her role. When the performance situation is presented in other contexts, more information appears. In Eiríks saga rauða 4, the elaboration of detail yields a deceptive verisimilitude that raises a flag of caution about taking it at face value. ${ }^{46}$ In Hrólfs saga kraka 3, minimal additional details are mentioned but do not seem of interest as such to the author. ${ }^{47}$ Saxo's Gesta Danorum VII.I.5 also gives a description of this episode in Hrólfs saga, but the description is problematic because it seems to conflate the volva's performance with a ritual performed by galdramenn 'incantation men' according to Hrólfs saga $\mathrm{I} . .^{8}$ The basic performance situation also seems to be the setting of the volva's speech in Voluspá, presented before the patriarch Óðinn and a broader audience. ${ }^{49}$ However, in dialogues with volur in the mythology, the volur seem to be raised from the dead and compelled to speak; they should thus not be assumed to accurately reflect the practices of volur in society.

These accounts suggest that a volva performed prophesies and perhaps imparted other knowledge ${ }^{50}$ at social events where she was hosted. The performance appears structured and may have been elaborate, including supporting roles. ${ }^{{ }^{\mathrm{I}}}$ The specific performance activities of a volva are uncertain..$^{52}$ However, the volva is represented as responding to questions in verse, ${ }^{53}$ which suggests that $a$ ) she was conscious, $b$ ) she mediated knowledge in direct interaction with others present, and $c$ ) she formulated responses in a form of aesthetically distinct verbal art. (N.B. - the Eddic form of the volva's responses may be a convention of the representation of verbal art in epic/saga genres rather than being historically accurate to a volva's mode of ritual speech.) Verse responses are introduced with the formulaic expression varð henni pá ljóð á munni 'then a song came into her mouth', which is linked to 
women's spontaneous verse speech. ${ }^{54}$ This formula situates agency and the source of information spoken outside of the woman, which could relate to the volva switching between first and third person in verses of Voluspá and Orvar-Odds saga. ${ }^{55}$ The volva nevertheless appears able to orchestrate inspired speech in a controlled way within the interactive framework of the ritual event. The mythic image volva would thus be characterized by a body image that is opened to external power or knowledge in contrast to the supernaturally closed body image of a berserkr. The wider use of the verðr e-m lióð á munni formula suggests an extension of the hegemonic body model that may be related to conceptions of gendered difference in open/closed, weak/strong or soft/hard bodies (as in Finno-Karelian tradition ${ }^{56}$ ). However, rather than the body image of a volva being a hegemonic body image at an extreme of openness, it was presumably supernaturally opened in a controlled and strategic way. The distinction of a berserk $r$ from other people in terms of his hamr presents the possibility that the volva's body image was also considered fractionally differentiated from the hegemonic norm. Such differentiation could account for volur being categorically distinguished according to descent from a primal origin alongside jotnar as if volur were a type of supernatural being. This interpretation remains conjectural, but it is not inherently improbable; it will be accepted here for the sake of argument.

\section{Deep-Trance Specialists}

There are a number of accounts of individuals who conceal their bodies under a covering or in a closed space during which an animal appears and acts on the performer's behalf or following which the performer possesses knowledge from remote locations. ${ }^{57}$ The performers are not identified with any single noun. Clive Tolley observes that the motif of covering the face or body in shamanic rituals exhibits an isogloss including Norse, Sámi and, to the east across the White Sea, Nenets, ${ }^{8}$ not to mention Irish to the west. ${ }^{59}$ This isogloss appears indicative of cross-cultural contacts. The Norse sources do not seem to distinguish between performances by Finnar ${ }^{60}$ and those by Norsemen. Treating practices as 
categorically equivalent across an otherwise socially significant Norse-Finnr ethnic divide suggests that they were completely "other" from the hegemonic perspective of the sources. Analysis is further complicated by the possibility that circulating discourse has homogenized diverse practices of both Norsemen and Finnar. As a result, traditionalization has subordinated practices that were historically distinct. Nevertheless, the model of practice in circulating discourse is fairly well represented and offers at least some perspective on formal aspects of a ritual practice.

The ritual separated the performer(s) physically or symbolically from others: the performer covered their body or head, or one or more performers enclosed themselves in a space so that the performance is completely concealed. As in later legends of Sámi shamanic rituals, there is no indication of performative activity per se. Nor is there any indication that it was orchestrated before an audience. The activity is distinct from murmuring into a cloak or skin and gaining access to knowledge while in a conscious state. ${ }^{6 \mathrm{I}}$ The performer is closed off from communication for the duration of the event, which is emphasized by a prohibition against speaking the performer's name until the performance is concluded. If an animal or monster appears and acts on the behalf of the performer, the length of the performance seems to correlate with the period during which the animal is active; when the performance concerns the acquisition of knowledge, it may last one or more days.

The description is consistent with a shamanic ritual involving a deep-trance state ${ }^{62}$ and journey of a free-soul and/or spirit helpers. Descriptions of animal agents acting on behalf of the performing individuals in sagas strikingly suggests that images of helping spirits or free-souls had advanced in circulating discourse from legends of encounters and conflicts in the supernatural world to interaction with heroes and their adversaries as agents physically present. In later legends, naming can disrupt magical transformations, ${ }^{63}$ which could potentially be linked to the naming prohibition. The Finnar maintained shamanic practices, as is evident from the exceptional account in the Historia Norwegiae. ${ }^{64}$ The trans-ethnic homogenization of representations in circulating discourse suggests that the ritual behaviour was not ethnically 
marked as it appears to be in later legends, with several implications: a) certain Norse practices were considered to be equivalent to the shamanic rituals of Finnar; $b$ ) the Norse practices may have been more prominent in shaping the representation in Norse circulating discourse than their counterpart(s) among Finnar; c) some sources may identify such practices with Finnar in narration as a strategy of "othering" rather than representing knowledge of the ethnicity of the specialists concerned; ${ }^{65} d$ ) some sources may disregard supernatural aspects in order to minimize the "othering" of the performer. ${ }^{66}$

The homogenization of practices makes it possible that several different technologies may have been conformed to this model of representation. It is not clear whether this practice was útisetja 'sitting out' ${ }^{67}$ or if útisetja may have been a term for a range of practices subordinated to this convention of representation. The descriptions could equally reflect the volva's technology orchestrated in private practice activity (and such practice by volur is not improbable). They could also reflect a vigil-like practice for summoning supernatural agents to mediate knowledge. ${ }^{68}$ Rituals for strategic and structured "dreaming" are also quite possible ${ }^{69}$ and would conform to dreams as an established venue in Norse culture for direct communication with supernatural agents, ${ }^{70}$ whose visitation could follow from being called on. ${ }^{7 \mathrm{I}}$ Nevertheless, the trans-ethnic homogenization with Finnar rituals indicates that, not only did the performances exhibit some formal parallels, but that at least some of the practices were marked as at an extreme of "otherness": they were not viewed as belonging to the society of "people like us". Moreover, the prohibition against naming the performer seems most likely to relate somehow to the performer's consciousness - some form of free-soul - being active as a goal-oriented agent while their body remained in one place. ${ }^{72}$ Vernacular ritual technologies dependent on a free-soul would thus depend on a body image very different from the Norse hegemonic model but consistent with that of Finnar. Whatever the rituals might have been, a physiological equivalence in "otherness" could account for the trans-ethnic homogenization of what were most likely ethnically distinct practices. 


\section{Perspectives}

Traditional motifs and narrative patterns in circulating discourse remain encoded with information about different types of specialist ritual performers and emblematic features of their abilities, of their practices, and of the outcomes of their practices. This information can be triangulated to hypothetically model understandings of the body image associated with these practitioners. The body image of the particular type of practitioner can then be viewed in relation to a probable Norse hegemonic norm of "people like us". In the case of berserkir, tentatively, performance appears to have sealed the body's boundary through aggression; this involved a process that was considered to exceed the capacities of a hegemonic body image and thus qualified as a change in hamr. In contrast, volur seem more likely to have strategically opened their bodies in performance in a controlled way that would allow them to mediate inspired speech from supernatural sources outside of themselves (however this may have been imagined). This opening of the body should not be misconstrued as passivity: volur are presented as respected supernaturally empowered agents. They are represented as being able to control what was or was not predicted, able to shape their predictions and even to construct fates through their performance. The body images of berserkir and volur appear most likely to reflect gendered difference in body images carried to supernaturally empowered extremes or ideals that simultaneously set them apart from other members of society. The deep-trance specialist is in some respects more ambiguous to approach. The conventional representation of this practice in circulating discourse suggests its central referent was a practice involving activity of a free-soul, and that this was perceived as wholly "other". This view reciprocally supports the theory that the hegemonic body image excluded the free-soul (as in Finno-Karelian cultures), or at least excluded a free-soul that could operate independently of the empirically perceivable body through the individual's conscious agency. Each of these three categories of practitioner appears to be characterized by a body image distinguished from the hegemonic norm. 
The verses of the epigraph to this chapter seem to suggest that different types of ritual performers were categorically distinguished by common origins like varieties of supernatural beings. The sources do not foreground this. Eiriks saga mentions that Pórbjǫrg litilvolva's nine sisters had all been spákonur 'prophesy-women'. ${ }^{73}$ The term hálf-berserkr 'half-berserkr'74 treats berserkr as an ethnic category, ${ }^{75}$ and Skalla-Grímr seems to inherit a changeable hamr from his father, although he is not called a berserkr ${ }^{76}$ while his son Egill exhibits a corresponding personality profile. ${ }^{77}$ At least in some sources, it appears that the "otherness" of these categorical identities was seen as inheritable, of which it seems body image was a likely part.

Each of the three cases above appears to be a practice-based institution. Although their ritual technologies are beyond reconstruction, it is clear that these practices depended on competence and could be strategically initiated with predictable outcomes. Each can thus be assumed to have relied on a ritual technology which could be used to situationally initiate the supernaturally empowered state. That technology would have been linked to social perceptions of competence and specialization, but it would also have been fundamental to training the presumably ecstatic behaviour as a response to performance and as essential to structuring and controlling the performer's experience..$^{78}$ In each case, the ritual technology can be assumed to be interfaced with the corresponding body image with which it engages. At the same time, the hegemonic body image can be assumed to have been interfaced with ritual technologies for healing, sex appeal and potency, protection from forces and agents in the environment, and so forth. In other words, "people like us" who were not specialized in ritual technologies would have internalized their body images in large part through practices related to their own bodies and the authorities who engaged those body image models in ritual and discourse. Such ritual practices might be described as "mainstream" technologies. The Finno-Karelian traditions suggest by analogy that berserkir could have or did employ (some of) the same "mainstream" technologies in berserksgangr. This is much less certain with volur, whose emblematic performance practices differed in complex ways. They appear to have used 
distinct genres of verbal art also in dialogic situational interaction. Attested Eddic poetry does not exhibit the flexibility and formulaic infrastructure conducive to appropriate situational improvisation. ${ }^{79}$ This women's poetry may have been in a separate poetic system equipped for this type of use. ${ }^{80}$ In this case, the mythology interfaced with the poetic system may have differed in significant ways from the mythology known through the Eddas and skaldic verse. ${ }^{8 \mathrm{I}}$ Their ritual practices may equally have operated through technologies markedly different from "mainstream" technologies, and the minimal variation from a hegemonic body image suggested here could be grossly oversimplified. Leaving aside the potential variety of practices that may be concealed behind representations of deep-trance specialists, central (though not necessarily all) technologies employed in these practices seem to have been interfaced with a body image marked as "other". They are likely to have not only been different from those of other specialists addressed here; they were potentially no less inconsistent with the technology of berserkir than Chinese acupuncture is with modern Western medicine (which does not prevent one person from using both). When considering the potential diversity of body images in an Old Norse milieu, it should be born in mind that these body images are not arbitrarily identified with different types of people; they are internalized and understood through practices, the ritual technologies on which these practices rely, and the broader range of circulating discourse. Identifying marked difference in body image between types of specialists thus becomes a crucial symptom of difference in the technologies on which their respective practices rely.

\section{Notes}

I. Voluspá inn skamma (Hyndluljóð 33).

2. See e.g. Stark 2006:I46-I62 and works there cited.

3. On circulating discourse, see Urban I99I:I-28 et passim; see also Urban I996:249-253. I use discourses in the plural because discourse is linked to social situations and to the groups and networks participating in those situations. As a consequence, not all discourse is 
uniformly accessible to everyone in a society and the different groups and networks can maintain multiple discourses in parallel.

4. In her research on mainly eighteenth-century Swedish vernacular religion, Van Gent (2009:I2) refers to this type of phenomenon as a "plurality of discourses of the self".

5. See also Lévi-Strauss I952:II-I6; de Castro I998:474-477; in Old Norse, see also Lindow I995:passim.

6. These discussions are often integrated into broader treatments of magic, ritual and religious practices, e.g. Strömbäck 2000 (I 935):I $50-$ I 90 but see also 220-236; Price 2002:224-227 et passim; Dillmann 2006:238-308; Heide 2006:passim; for extensive chapters devoted to the topic, see Tolley 2009 I:I67-27I.

7. Price 2002:366-388; Dillmann 2006:26I-268; Tolley 2009 I: $563-579$.

8. Recent monographs devoted to the topic of bersirkir are Samson 20I I and Dale 20I4.

9. Tolley 2009 I:463-5I7 and see also I76-I99, esp. I93, I99, and 589.

Iо. For discussion and references see Frog 2013, esp. 59-68.

I I. See Stark 2006:I46-I62, 254-3 56, 45 I-458.

I2. The term 'shamanism' has a problematic history of use (for an extreme view, see Rydving 20II). It is here used in the narrow sense of Central and Northern Eurasian traditions or 'classic shamanism' (Siikala I 978:I4-I 5), which are characterized by a system of features that take culture-specific forms within local religious and mythological frameworks. Problems in applying classic shamanism to ProtoSámi (on which see Frog 2017:6I) do not extend to features relevant to the present discussion.

I3. Frog 2013:59-68, 73-74, 80-84, 87-9I.

I4. Christiansen I958: type 3080; Jauhiainen I998: types Dio3 II040; af Klintberg 2010: types MI 5 I-I60.

I 5. E.g. af Klintberg 20I0:QII-20. A notable exception is a migratory legend-type and its variations in which the image of a free-soul 
is structurally interfaced with the plot $(\mathrm{Q} I-3)$. Already Lauri Honko (I960) observed that these models vary by genre: motifs of 'soul loss' could appear in Finno-Karelian genres that do not seek full verisimilitude with social life, such as folktales and epic, while remaining absent from illness diagnostics and healing practices. Note that the distinction foregrounded here has often been overlooked or not considered significant: the Cartesian model of the mind/spirit as separate from the body seems to have led the interpretation of the vernacular traditions, and also earlier led me to view such stories through the lens of 'soul journeys'. Emphasis here is also on models circulating in narrative traditions and ritual practices and does not exclude the idea that individual accounts referring to separation of $\mathrm{mind} / \mathrm{soul}$ and body might be found, for example, in court records (cf. Van Gent 2009:79-85), where this remains unclear.

I6. Kanerva 201 5:93-94, I35-I44. Van Gent (2009, esp. Ch. 3) discusses the penetrable body interfaced with Swedish vernacular magic and ritual but her focus is the "semantics" of the magical body as reflecting social tensions without exploring how the dynamics of penetrability or forces affecting it were conceived.

I7. Lotman I990:I30.

I 8. See also Tulinius 2002, esp. 65-68.

I9. The emblematic ritual context of a volva's performance is described as an itinerant practice in which the volva would move from location to location as a guest of honour at feasts that were presumably costly to each in the series of hosts. If any volur immigrated to Iceland, there is no reason to assume that the practice would be embraced locally or regionally, or even that it persisted on a single farm across generations. 20. E.g. Kristni saga 2, 9; Grágás 7; Dale 20I4:I40-I4I, 3 I4-3 I9; in contrast, translation literature from Norway includes Christian berserkir and historical records show berserkr as an epithet of Christians as late as the I $4^{\text {th }}$ century (Samson 2OII:225-226; Dale 20I4:I8OI $83 ; 200-202$ ).

2 I. On this ritual, see Jón Hnefill Aðalsteinsson I978:esp. Ch.I3.

22. Urban I99I:I; I edit Urban's “publicly” to “socially” to accommodate cultural elements transmitted in contexts closed to some 
members or perhaps the majority of a society and that may thus be socially but not publicly accessible.

23. The approach to mythic discourse used here is introduced more fully in Frog 2015.

24. Siikala 2012:I9.

25. Samson 20II:238-240 and Dale 20I4:I39-I42.

26. E.g. Kristni saga 2, 9.

27. See further Frog 20I 5:38-4I.

28. Christiansen I958:3080; Jauhiainen I998:DI03I-I040; af Klintberg 20I0:MI 5 I-I60.

29. See Samson 20I I: I 5I-I 56, I98-225; Dale 20I4:I I I-I I4.

30. Samson 20II:227-232; Dale 20I4:7I-98, I47-I62; Gesta Danorum VII.2.7:I 85 correlates sorcery directly with this performance behaviour.

3I. Samson 20II:236-240; Dale 20I4:I39-I45.

32. E.g. Hálfdanar saga Eysteinssonar I6, 20.

33. Cf. Hávamál I 48.

34. Dale 2OI4:I42-I46.

35. Dale 20I 4: I 20-I 27; for a view linking this vocabulary to transformation, see Samson 20I I:244-260; see also Bourns 20I 7:2 I 5-225.

36. Dale 20I4:I42.

37. Dale 2014:162-163.

38. On the specialist's trance techniques, see Siikala 2002:242-250; on increased 'hardness' of the body in this state, see Stark 2006:3 IO-3 I 4. 39. See also Price 2002, Ch. 6.

40. The incantation tradition is generally informed by the semiotics of Iron Age warfare and so ritual defences against physical and supernatural harm converge, noting that with modernization such rituals also provided protection against bullets (see e.g. Siikala 2002:28 I294; Stark 2006:279-28I). 
4I. Bourns similarly stresses that the verb hamask, related to hamr, can mean either to change appearance or, as he puts it, "to change temperament and enter a wild frenzy, like a berserkr" (2017:2I9; cf. Cleasby \& Vigfusson I 896, s.v. hamask; ONP, s.v. hama).

42. See McKinnell 2003:I I 8-I I9.

43. Cf. Sámi being identified as supernaturally empowered agents in a variety of legend-types (e.g. af Klintberg 2010:M32, 43, 6I-65, I07, I35) but remaining the only agents in legends of deep trance rituals.

44. McKinnell 2003:I22-I25. This narrative pattern appears with a full performance context in Qrvar-Odds saga 2, Orms páttr Stórólfssonar 5, Vatnsdcela saga 1о, and with the role of the volva filled by the mother of the king (not called a volva) in Flateyjarbók's Óláfs saga Tryggvasonar 50 ; cf. also Flateyjarbók's Óláfs saga helga 25. The production of written accounts of the performance context in these and other sources no doubt played a part in its evolution in circulating discourse, but the body of sources suggests a vital position in ultimately oral discourse rather than a literary invention.

45. See also Frog 20I4, esp. 28.

46. Tolley 2009 I:487-498; see also Egeler 20 I 5:88.

47. See also Egeler 201 5:87-88.

48. Saxo's volva tries to acquire objects from a remote location (children!), falls unconscious, and, whereas she interrupts her visionary performance in Hrólfs saga 3 when a physically present person throws gold into her lap, the people in the physically remote location threw gold into her lap according to Saxo.

49. Voluspá I.

50. Hrólfs saga 3 (paralleled in Gesta Danorum; cf. also Voluspá) may suggest that a volva could also find lost and stolen objects, but this might simply be the result of subordinating the ritual to the saga's plot.

5I. Eiriks saga links the event to the saga through a supportive singer in the ritual. Within the narrative, the volva's prophesy for this individual equates to a reward for assistance, which makes it seem more 
likely to reflect circulating discourse of supporting singing than an authorial invention to motivate the reward. Saxo also mentions the volva's assistants where these are structurally relevant to narration. If the volva was an itinerant specialist hosted at a feast of any magnitude, a correspondingly elaborate performance can be expected.

52. Eiríks saga and Hrólfs saga mention that performance is on a seiðhjallr 'scaffold for performing magic (seiðr)'. However, in narrative discourse, a seiðhjallr was a characteristic location for a formalized pagan ritual performance (see also Sundqvist 20I 2:28I-283). The writers or redactors of these two sagas (or their informants) may have independently added this detail as an elaboration with a commonplace from the discourse on pagan practices without a historical link to a volva's performance per se. In Lokasenna 24, Loki insults Óðinn for 'tapping on a vétt like a volva' (draptu á vétt sem volor), but alliteration between vétt and volva presents the possibility that either word could be a poetic alternative for another noun and thus may not refer to the activity of a volva as a type of specialist.

53. Qrvar-Odds saga 2; Orms páttr 5; Hrólfs saga 3; Saxo also stresses her carmina 'songs; oracular responses', but his account is problematic.

54. For a survey and discussion of this formula, see Quinn 1998.

55. Hrólfs saga mentions that the volva yawns a great deal before her first prophetic speech. This has been interpreted as taking spirits into her body (Tolley 1995:58; Price 2002:209), but motifs of yawning and becoming drowsy are generally associated with supernatural contact (Strömbäck 2000 (I935):I 52-I 59; Njáls saga I3:37 n.7; Jón Hnefill Aðalsteinsson I978:I09-I2 I. This motif could have been linked to the volva's performance as an elaboration with no connection to historical practices.

56. See Stark 2006:264-265.

57. E.g. Strömbäck 2000 (I935):I60-206; Jón Hnefill Aðalsteinsson I978:II3-I23; Price 2002:36I-362.

58. Tolley 2009 I:260.

59. Jón Hnefill Aðalsteinsson I978: I I6-I I7. 
60. Most likely speakers of Southwest Proto-Sámi.

6I. Jón Hnefill Aðalsteinsson I978: I IO-I I3; cf. Njáls saga I3:37 n. 9. 62. My thanks to Jens Peter Schjødt for pointing out that "unconscious trance" is a problematic overgeneralization. On different depths of trance in relation to types of performance, see Siikala $1978: 338-339$.

63. E.g. af Klintberg 2010:Q42-43, 45-46.

64. On this account, see Tolley 2009 I:258-268.

65. Cf. the volva as a Finna in Vatnsdcela saga ro; for discussions of how magic is used and manipulated in discourse, see e.g. Stark 2006; Van Gent 2009; Meylan 20I4.

66. E.g. Porgeirr Porkelsson's performance.

67. E.g. Strömbäck 2000 (I935):I26-I29; Dillmann 2006:42-44; Tolley 2009 II:I33-I34.

68. Cf. Jón Árnason I 862:436-438.

69. Ef. Jón Hnefill Aðalsteinsson I978: I I6-I I 7.

70. See e.g. Kelchner 1935:66-72.

7I. E.g. Porláks saga biskups 28, 65-67, 69, 8I.

72. Cf. also Siikala $1978: 339$ on deep trance and interaction with non-performers.

73. Eiríks saga 4 .

74. Svarfdoela saga 7.

75. With the exception of half-troll 'half-troll', it is characteristic of such 'half-breed' terms that they appear as hapax legomena - e.g. hálf-bergrisi 'half-mountain-giant', hálf-risi 'half-giant', hálf-Finnr 'half-Finnr', hálf-Karell 'half-Karelian'.

76. Eigils saga 40.

77. See also Samson 20I I:I 5 I-I 56.

78. See also Siikala I978, esp. 49-52 and 339 on shamans' performances. 79. Frog 20II:I9-28 and works there cited. 
8०. This has been suggested by Eila Stepanova for women's lament poetry (20II:I4O; cf. also Mundal 20I3:368-379).

8I. Cf. the differences between the mythology of Karelian lament poetry and the Kalevalaic epic and incantation poetry with which it co-existed for centuries, discussed in Stepanova 20I 2:265-28I.

\section{References}

Primary sources

Egils saga. Íslenzk Fornrít II. Reykjavík: Hið Íslenzka Fornritafélag.

Eiríks saga rauða. Íslenzk Fornrít IV. Reykjavík: Hið Íslenzka Fornritafélag.

Flateyjarbók. Guðbrandur Vigfússon \& Carl Rikard Unger (eds.) I 860-I 868. Flateyjarbók: En samling af norske konge-sagaer I-III. Christiania: P.T. Mallings Forlagsboghandel.

Gesta Danorum. Olrik, J. \& H. Ræder (eds.) I93I. Saxonis Gesta Danorum. Hauniæ: Levin \& Munksgaard.

Grágás. Vilhjálmur Finsen (ed. \& trans.). I 852 . Grágás. Isloendernes lovbog i fristatens tid, udg. efter det kongelige Bibliotheks haanskrift I-II. Copenhagen: Berling.

Hálfdanar saga Eysteinssonar. Guðni Jónsson \& Bjarni Vihjálmsson (eds.). I943-I944. Fornaldarsögur Norðurlanda III. Reykjavik: Bókaútgáfan Forni, 285-3 I9.

Hávamál. Neckel, Gustav \& Kuhn, Hans. I963. Edda. Die Lieder des Codex Regius nebst vewandten Denkmälern I: Text. $4^{\text {th }}$ Edition. Heidelberg: Carl Winters Universitätsbuchhandlung, I 7-44.

Historia Norwegie. Ekrem, Inger \& Boje Mortensen, Lars (eds.). 2006. Historia Norwegie. Trans. Peter Fisher. Copenhagen: Museum Tusculanum Press.

Hrólfs saga kraka. Guðni Jónsson \& Bjarni Vihjálmsson (eds.). I943I944. Fornaldarsögur Norðurlanda II. Reykjavik: Bókaútgáfan Forni, 3-93. 
Hyndluljóð. Neckel, Gustav \& Kuhn, Hans 1963. Edda. Die Lieder des Codex Regius nebst vewandten Denkmälern I: Text. $4^{\text {th }}$ Edition. Heidelberg: Carl Winters Universitätsbuchhandlung, 288-296.

Kristni saga. Hannes Finnsson (ed.). I773. Kristni-saga, sive Historia Religionis Christiance in Islandiam introducto; nec non Pattr af Isleifi Biskupi, sive Narratio de Isleifo Episcopo: Ex Manuscriptis Legati Magnoeani. Hafnia: Frid. Christian Godiche.

Lokasenna. Neckel, Gustav \& Kuhn, Hans. 1963. Edda: Die Lieder des Codex Regius nebst vewandten Denkmälern I: Text. $4^{\text {th }}$ Edition. Heidelberg: Carl Winters Universitätsbuchhandlung, 96-I Io.

Njáls saga. Íslenzk Fornrít XII. Reykjavík: Hið Íslenzka Fornritafélag. Óláfs saga helga, see Flateyjarbók.

Óláfs saga Tryggvasonar, see Flateyjarbók.

Orms páttr Stórólfssonar. Íslenzk Fornrít XIII. Reykjavík: Hið Íslenzka Fornritafélag.

Qrvar-Odds saga. Íslenzk Fornrít I. Reykjavík: Hið Íslenzka Fornritafélag, 283-399.

Svarfdcela saga. Íslenzk Fornrít IX. Reykjavík: Hið Íslenzka Fornritafélag.

Porláks saga biskups. Íslenzk Fornrít XVI. Reykjavík: Hið Íslenzka Fornritafélag.

Vatnsdcela saga. Íslenzk Fornrít VIII. Reykjavík: Hið Íslenzka Fornritafélag.

Voluspá. Neckel, Gustav \& Kuhn, Hans. 1963. Edda. Die Lieder des Codex Regius nebst vewandten Denkmälern I: Text. $4^{\text {th }}$ Edition. Heidelberg: Carl Winters Universitätsbuchhandlung, I-I 6 .

Secondary literature

Bourns, Timothy J. S. 2017. Between Nature and Culture. Animals and Humans in Old Norse Literature. Unpublished PhD dissertation. Oxford: University of Oxford.

de Castro, Eduardo Viveiros. 1998. Cosmological Deixis and Amerindian Perspectivism. In Journal of the Royal Anthropological Institute, vol. 4, no. 3, 469-488. 
Christiansen, Reidar Th. 1958. The Migratory Legends. A Proposed List of Types with a Systematic Catalogue of the Norwegian Variants. Folklore Fellows' Communications I75. Helsinki: Academia Scientiarum Fennica.

Cleasby, Richard \& Gudbrand Vigfusson I 896. An Icelandic English Dictionary Chiefly Founded on the Collections made from Prose Works of the I2th-I4th Centuries. Oxford: Clarendon Press.

Dale, Roderick Thomas Duncan. 20I4. Berserkir. A Re-Examination of the Phenomenon in Literature and Life. $\mathrm{PhD}$ dissertation, University of Nottingham. Available at: http://eprints.nottingham. ac.uk/288I9/.

Dillmann, François-Xavier. 2006. Les magiciens dans l'Islande ancienne. Etudes sur la representation de la magie islandaise et de ses agents dans les sources litteraires norroises. Acta Academiae Regiae Gustavi Adolphi, 92. Uppsala: Kungl. Gustav Adolfs Akademien för Svensk Folkkultur.

Egeler, Matthias. 2015. A Retrospective Methodology for Using Landnámabók as a Source for the Religious History of Iceland? Some Questions. In RMN Newsletter, vol. Io, 78-92.

Frog. 20II. Alvíssmál and Orality I: Formula, Alliteration and Categories of Mythic Being. In Arkiv för Nordisk Filologi, vol. I 26, I7-7I.

Frog. 2013. Shamans, Christians, and Things in Between. From FinnicGermanic Contacts to the Conversion of Karelia. In L. Słupecki \& R. Simek (eds.). Conversions. Looking for Ideological Change in the Early Middle Ages. Studia Mediaevalia Septentrionalia, 23. Vienna: Fassbaender, 53-98.

Frog. 20I4. Germanic Traditions of the Theft of the ThunderInstrument (ATU II48b). An Approach to Prymskviða and Pórr's Adventure with Geirrøðr in Circum-Baltic Perspective. In E. Heide \& K. Bek-Petersen (eds.). New Focus on Retrospective Methods. Resuming Methodological Discussions. Case Studies from Northern Europe. Folklore Fellows' Communications 307. Helsinki: Academia Scientiarum Fennica, I I 8-i60.

Frog. 2015. Mythology in Cultural Practice. A Methodological Framework for Historical Analysis. In RMN Newsletter, vol. 
Io (special issue: Frog \& Karina Lukin (eds.) Between Text and Practice: Mythology, Religion and Research), 33-57.

Frog. 20I7. Sámi Religion Formations and Proto-Sámi Language Spread. Reassessing a Fundamental Assumption. In RMN Newsletter, vol I 2-I3, 36-69.

Heide, Eldar. 2006. Gand, seid og andevind. PhD dissertation. Bergen: Universitetet i Bergen.

Honko, Lauri. 1960. Varhaiskantaiset taudinselitykset ja parantamisnöytelmä. In J. Hautala (ed.). Jumin keko. Tutkielmia kansanrunoustieteen alalta. Helsinki: Suomaliasen Kirjallisuuden Seura, 4I-III.

Jauhiainen, Marjatta. 1998. The Type and Motif Index of Finnish Belief Legends and Memorates. Folklore Fellows' Communications 267. Helsinki: Academia Scientiarum Fennica.

Jón Árnason I 862. Íslenzkar pjóðsögur og cefintýri I. Leipzig: J.C. Hinrichs.

Jón Hnefill Aðalsteinsson. 1978. Under the Cloak. A Pagan Ritual Turning Point in the Conversion of Iceland. Studia Ethnologica Upsaliensia, 4. Uppsala: Almqvist \& Wiksell International.

Kanerva, Kirsi. 2015. Porous Bodies, Porous Minds. Emotions and the Supernatural in the Íslendingasögur (ca. I200-I400). Annales Universitatis Turkuensis, B, 398. Turku: University of Turku.

Kelchner, Georgia Dunham. 1935. Dreams in Old Norse Literature and Their Affinities in Folklore. Cambridge: Cambridge University Press.

af Klintberg, Bengt. 2010. The Types of the Swedish Folk Legend. Folklore Fellows' Communications 300. Helsinki: Academia Scientiarum Fennica.

Lévi-Strauss, Claude. 1952. Race and History. Paris: UNESCO.

Lindow, John. 1995. Supernatural Others and Ethnic Others. A Millennium of World View. In Scandinavian Studies, vol. 67, no. I (special issue: John Lindow \& Timothy R. Tangherlini (eds.). Nordic Legends and the Question of Identity), 8-3 I. 
Lotman, Yuri M. I990. Universe of the Mind. A Semiotic Theory of Culture. Bloomington: Indiana University Press.

McKinnell, John. 2003. Encounters with Völur. In M. Clunies Ross (ed.). Old Norse Myths, Literature and Society. Viking Collection, I4. Viborg: University Press of Southern Denmark, I IO-I3 I.

Meylan, Nicolas. 20I4. Magic and Kingship in Medieval Iceland. The Construction of a Discourse of Political Resistance. Studies in Viking and Medieval Scandinavia 3. Turnhout: Brepols.

Mundal, Else. 2013. Female Mourning Songs and Other Lost Oral Poetry in Pre-Christian Nordic Culture. In L. Boje Mortensen et al. (eds.). The Performance of Christian and Pagan Storyworlds. NonCanonical Chapters of the History of Nordic Medieval Literature. Turnhout: Brepols, $367-388$.

ONP = Ordbog over det norrøne prosasprog - The Dictionary of Old Norse Prose. Available at: https://onp.ku.dk.

Price, Neil S. 2002. The Viking Way. Religion and War in Late Iron Age Scandinavia. Uppsala: University of Uppsala.

Quinn, Judy. I998. 'Ok verðr henni ljóð á munni’. Eddic Prophecy in the Fornaldarsögur. In Alvísmál, vol. 8, 29-50.

Rydving, Håkan. 20 I I. Le chamanisme aujord'hui. Constructions et deconstructions d'une illusion scientifique. In Études mongoles et sibériennes, centrasiatiques et tibétaines, vol. 42, I-I3.

Samson, Vincent. 20II. Les Berserkir. Les guerriers-fauves dans la Scandinavie ancienne, de l'Âge de Vendel aux Vikings (VIe-XIe siècle). Lille: Presses Universitaires du Septentrion.

Siikala, Anna-Leena. 1978. The Rite Technique of the Siberian Shaman. Folklore Fellows' Communications 220. Helsinki: Academia Scientiarum Fennica.

Siikala, Anna-Leena. 2002. Mythic Images and Shamanism. A Perspective on Kalevala Poetry. Folklore Fellows' Communications 280. Helsinki: Academia Scientiarum Fennica.

Siikala, Anna-Leena. 20I2. Myths as Multivalent Poetry. Three Complementary Approaches. In Frog et al. (eds.). Mythic 
Discourses. Studies in Uralic Traditions. Studia Fennica Folkloristica, 20. Helsinki: Finnish Literature Society, I7-39.

Stark, Laura. 2006. The Magical Self. Body, Society and the Supernatural in Early Modern Rural Finland. Folklore Fellows' Communications 290. Helsinki: Academia Scientiarum Fennica.

Stepanova, Eila. 20I I. Reflections of Belief Systems in Karelian and Lithuanian Laments. Shared Systems of Traditional Referentiality? In Archaeologia Baltica, vol. I 5 (special issue: D. Vaitkevičienė \& V. Vaitkevičius (eds.). Archaeology, Religion and Folklore in the Baltic Sea Region), I28-I43.

Stepanova, Eila. 20I 2. Mythic Elements of Karelian Laments. The Case of syndyzet and spuassuzet. In Frog et al. (eds.). Mythic Discourses. Studies in Uralic Oral Traditions. Studia Fennica Folkloristica, 20. Helsinki: Finnish Literature Society, 257-287.

Strömbäck, Dag. 2000 (1935). Sejd och andra studier i nordisk själsuppfattning. Acta Academiae Regiae Gustavi Adolphi, 72. Hedemora: Gidlunds Förlag.

Sundqvist, Olof. 20I2. Var sejdhjällen (fvn. seiðhjallr, hjallr) en permanent konstruktion vid kultplatser och i kultbyggnader? In Fornvännen 107, 280-285.

Tolley, Clive. 1995. Vorðr and Gandr. Helping Spirits in Norse Magic. In Arkiv för Nordisk Filologi, vol. I Iо, 57-75.

Tolley, Clive. 2009. Shamanism in Norse Myth and Magic I-II. Folklore Fellows' Communications 296-297. Helsinki: Academia Scientiarum Fennica.

Tulinius, Torfi H. 2002. The Matter of the North. The Rise of Literary Fiction in Thirteenth-Century Iceland. Trans. Randi C. Eldevik. Viking Collection, I3. Odense: Odense University Press.

Urban, Greg. I99I. A Discourse-Centered Approach to Culture. Native South American Myths and Rituals. Austin: University of Texas Press.

Urban, Greg. 1996. Metaculture. How Culture Moves through the World. Minneapolis: University of Minnesota Press.

Van Gent, Jacqueline. 2009. Magic, Body and the Self in EighteenthCentury. Leiden: Brill. 


\section{Response}

\section{Margaret Clunies Ross}

University of Sydney

\section{The Approach}

In this chapter Frog looks for Old Norse-Icelandic textual evidence for the relationship between embodied experience and the ritual technologies assumed to have been practised in "the Old Norse world". The time period covered by his enquiry is not precisely defined, but the source material he uses dates mostly from the medieval period and is mostly Icelandic, at least in the form we have received it. He also looks to identify different types of ritual specialist evidenced in Old Norse sources, as well as evidence for the interface between ritual technologies, body images and understandings of the unseen world. He frequently backs up his findings by comparisons with Finno-Karelian legendary traditions. Some of his remarks suggest that concepts of the penetrable body and the free-soul may have entered the Scandinavian tradition from North Finnic cultures, but his position on this does not emerge clearly. What he does credibly argue is that the three case studies he analyses in this chapter establish the body images of the various practitioners based on an ethnocentric norm of "people like us" which includes a hegemonic body image of a penetrable body as a frame of reference.

\section{Methodology}

Although Frog recognises that most of the surviving texts at our disposal were written by Christians "writing for Christian audiences in a form of heritage construction", his approach to the sources assembled to support his description of three different types of ritual practitioner (berserkr, volva, deep-trance specialist) does not discriminate clearly between these sources in terms of their likely source value to a mythographer and the likely intellectual background to their articulation. This leads to a picture of 
a type of ritual practitioner in which more or less equal weight is given to the different kinds of evidence assembled, and this may be misleading in the context of research into the underlying conceptual world of early Scandinavians.

\section{The Berserkr}

The methodological difficulty mentioned above is particularly apparent in Frog's treatment of the category of berserkr (if indeed berserks were ritual specialists, something for which there is little evidence). The berserkr is presented as "a supernaturally empowered warrior", and yet there is no unquestionable evidence in the sources to support this view. If berserks were supernaturally empowered, what force empowered them? Where berserks first appear in Old Norse texts, in the late ninth- or early tenthcentury poem Haraldskvœði by Porbjǫrn hornklofi (stanzas 8 and 2I), they are not attributed with supernatural powers but rather with ferocious physical strength; they are called "wolf-skins", they howl and brandish iron spears; they are Haraldr Fine-hair's crack troops. Their name has suggested to many that they wore animal skins over their armour (or, on an alternative etymology, that they wore no body armour). Some saga texts of later date, where berserks appear as highly conventionalised, often pagan, trouble-makers, associate berserks with being impervious to iron weapons, a motif not exclusive to them alone, however. There are also some places where they are reported as claiming to be able to resist fire, but in most cases of the latter type, the fire motif should likely be understood as influenced by, and possibly generated by, Christian concepts of the ordeal as a test of a person's merit, whether physical or spiritual or both. It is also notable that in the examples of berserks claiming imperviousness to fire (Kristni saga and related texts), they are represented as doing so in the context of trials of strength with Christian authorities, and they fail the fire test miserably, thus demonstrating the superiority of their Christian opponents.

Whether the association with imperviousness to fire points to a once active pre-Christian belief in supernatural powers possessed 
by such warriors is a matter for speculation. This possibility is, however, enhanced by the fact that the Christian Laws section of Grágás ${ }^{\mathrm{I}}$ lists falling into a berserk frenzy among the magical practices that attract a penalty of lesser outlawry. The fact that the berserksgangr 'berserk frenzy' (literally 'berserk's rush') is mentioned in the context of magical practices that people ought to control or discontinue suggests that in medieval times it was considered to be a learned human behaviour, and in that respect, I agree with Frog that it must have been "a trained behaviour of heightened (but directionally controlled) aggression”. Whether this also implied a closed body image, as he maintains, is a little more dubious: the associations of the berserkr with invulnerability to iron and fire are very general motifs, and may not have been unique to the berserk's image, whereas the berserksgangr, which implies an outward flow or passage (gangr) of aggression, seems to require the body to allow its powers to surge forth beyond its confines.

Oddly enough, Frog does not adduce the one piece of textual evidence that might support his case for the berserk as supernaturally empowered, and possibly being associated with a cult of Óðinn. This is the passage in Ynglinga saga Chapter $6^{2}$ that is also one of the main sources of our information about the berserksgangr. In this source berserks are warriors firmly associated with the euhemerised Óðinn as his men who went without armour, crazed as dogs or wolves, biting their shields, killing men and being affected by neither fire nor iron while in the berserk state. In the following chapter, ${ }^{3}$ Ódinn is revealed as a shape-changer par excellence (Óðinn skipti homum) and a master of out-of-body experiences, taking the form of a bird, animal, fish or snake, while his body lies as if asleep or dead (lá pá búkrinn sem sofinn eða dauðr). As John Lindow has observed, ${ }^{4}$ Óðinn is here presented, not as a deity, but as a human shaman, imbued with the powers that Snorri knew Saami sorcerers possessed, and, in the euhemerised context of Ynglinga saga, as teaching this technology to the native Scandinavians, who came to regard him as a god. This context suggests that berserk behaviour was also something the pre-Christian Scandinavians thought came from the euhemerised Óðinn. 


\section{The Volva and the Deep-Trance Specialist}

The remaining two categories of ritual practitioner identified in Frog's chapter, the volva and the deep-trance specialist, are more readily acceptable as such than the berserkr. In general, Frog's descriptions of these practitioner types seem valid, though there are a good number of questions arising, as he admits, because of our lack of evidence. Many of the inferences he draws from the available sources are speculative and cannot be verified, even with his frequent recourse to Finno-Karelian traditions of post-medieval date and provenance. In the case of the volva, a body image gendered female, what is the connection between the volur depicted in saga literature, itinerant soothsayers performing their rites for a fee before audiences of farm communities, and the volur of mythological poetry raised involuntarily from a death-like state by Óðinn to inform him of the fates of the gods, the cosmos and his own dead son, which, perhaps, he already knows? And what of the gods' killing of Gullveig or Heiðr in Voluspá 2I-22 (the latter a name commonly applied to the volur of saga literature)? It seems that there may be a bridge between the human and the divine in this case, though Frog does not mention this enigmatic passage.

$\mathrm{He}$ is certainly right that, whereas the volva requires an audience, whether of one or many, the deep-trance specialist is separated from society by virtue of the nature of the ritual he performs. What is interesting but perhaps controversial in Frog's presentation here is not so much his identification of this ritual type as shamanic, involving an unconscious trance-like state and journey of a free-soul and/or spirit helpers, as in Ynglinga saga's description of the euhemerised Óðinn, but his contention that there is "trans-ethnic homogenization of representations in circulating discourse suggest[ing] that the ritual behaviour was not ethnically marked as it appears in later legends". In other words, such practices associated with ethnic Scandinavians are not differentiated in Old Norse-Icelandic sources in terms of their presentation of the ritual itself or its performer from those associated with 'Finnar' 'Saami', except where the practitioners are identified as Saami in order to mark the behaviour as 'other'. Unfortunately, 
Frog does not give any examples to support this contention, except for an allusion to the episode recorded by Ari Porgilsson in Íslendingabók in which the then law-speaker Porgeirr Porkelsson lay down under his cloak for a day and a night, in order to decide whether Iceland should adopt Christianity or not. Although this episode has been interpreted as shamanic, ${ }^{5}$ not everyone accepts this understanding of Porgeirr's behaviour, for which Ari himself gives no explanation.

\section{Notes}

I. K 7; 'Grágás' I a:23; Dennis et al. I980:39.

2. Íslenzk Fornrit XXVI:I7.

3. Íslenzk Fornrit XXVI:I 8.

4. Lindow 2003:97-106.

5. Jón Hnefill Aðalsteinsson I999:103-I23.

\section{References}

Andrew, Dennis et al. (trans.). I980. Laws of Early Iceland. Grágás I. Winnipeg: University of Manitoba Press.

Vilhjálmur Finsen (ed.). I 852 . Grágás. Islaendernes lovbog i fristatens tid, udgivet efter det Kongelige Bibliotheks haandskrift. Copenhagen: Berling. Rpt 1974 Odense: Odense University Press.

Bjarni Aðalbjarnarson (ed.). I94I. Snorri Sturluson. Heimskringla I. Íslenzk fornrit XXVI. Reykjavík: Hið Íslenzka Fornritafélag.

Jón Hnefill Aðalsteinsson. 1999. Under the Cloak. A Pagan Ritual Turning Point in the Conversion of Iceland. Second ed. Reykjavík: Félagsvísindastofnun, Háskólaútgáfan.

Lindow, John. 2003. Cultures in Contact. In M. Clunies Ross (ed.). Old Norse Myths, Literature and Society. The Viking Collection I4. Odense: University Press of Southern Denmark, 89-ı09. 
